\title{
Elemental quantification, chemistry, and source apportionment in golf course facilities in a semi-arid urban landscape using a portable X-ray fluorescence spectrometer
}

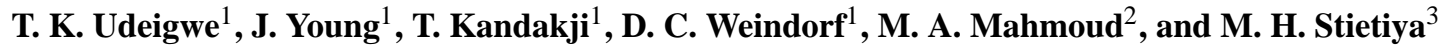 \\ ${ }^{1}$ Department of Plant and Soil Science, Texas Tech University, Lubbock, TX 79409, USA \\ ${ }^{2}$ Soils, Water and Environment Research Institute (SWERI), Agricultural Research Center (ARC), Giza, Egypt \\ ${ }^{3}$ Department of Land, Water, and Environment, The University of Jordan, Amman, Jordan \\ Correspondence to: T. K. Udeigwe (theo.udeigwe@ttu.edu)
}

Received: 10 November 2014 - Published in Solid Earth Discuss.: 6 January 2015

Revised: 17 March 2015 - Accepted: 20 March 2015 - Published: 22 April 2015

\begin{abstract}
This study extends the application of the portable $\mathrm{X}$-ray fluorescence (PXRF) spectrometry to the examination of elements in semi-arid urban landscapes of the Southern High Plains (SHP) of the United States, focusing on golf courses. The complex environmental challenges of this region and the unique management practices at golf course facilities could lead to differences in concentration and in the chemistry of elements between managed (irrigated) and non-managed (non-irrigated) portions of these facilities. Soil samples were collected at depths of 0-10, 10-20, and 20$30 \mathrm{~cm}$ from managed and non-managed areas of seven different facilities in the city of Lubbock, Texas, and analyzed for a suite of soil properties. Total elemental quantification was conducted using a PXRF spectrometer. Findings mostly indicated no significant differences in the concentration of examined elements between the managed and non-managed areas of the facilities. However, strong positive relationships $(R=0.82-0.91, p<0.001)$ were observed among elements (e.g., Fe on the one hand and $\mathrm{Cr}, \mathrm{Mn}, \mathrm{Ni}$, and $\mathrm{As}$ on the other; $\mathrm{Cu}$ and $\mathrm{Zn}$; $\mathrm{As}$ and $\mathrm{Cr}$ ) and between these elements and soil constituents or properties such as clay, calcium carbonate, organic matter, and $\mathrm{pH}$. The strengths of these relationships were mostly higher in the non-managed areas, suggesting a possible alteration in the chemistry of these elements by anthropogenic influences in the managed areas. Principal component and correlation analyses within the managed areas suggested that $\mathrm{As}, \mathrm{Cr}, \mathrm{Fe}, \mathrm{Mn}$, and $\mathrm{Ni}$ could be of lithogenic origin, while $\mathrm{Cu}, \mathrm{Pb}$, and $\mathrm{Zn}$ could have anthropogenic influences. Only one possible, likely lithogenic, source of the el-
\end{abstract}

ements was identified within the non-managed areas. As evidenced by the study, the PXRF spectrometer can be a valuable tool for elemental quantification and rapid investigation of elemental interaction and source apportionment in semiarid climates.

\section{Introduction}

Inorganic pollutant contamination of soil and water is an issue of concern worldwide with regard to the environment and human health (Vacca et al., 2012; Roy and McDonald, 2015). Elemental contaminants vary in source, form, level, and fate within landscapes and various land uses, and they are generally impacted by geological formations, climatic conditions, and anthropogenic influences (Kabata-Pendias, 2010). It is therefore important to conduct site-specific evaluations in any environmental quality assessment and remediation effort. In an attempt to overcome the lag time associated with conventional wet-chemistry analyses, the rapid quantification of contaminants using advanced technologies, such as portable X-ray fluorescence (PXRF) spectrometry, is gaining importance in the fields of soil and environmental sciences (Weindorf et al., 2012a; McWhirt et al., 2012; Gardner et al., 2013; Hu et al., 2014). PXRF spectrometry has been a valuable tool in the quantification of contaminants (Clark and Knudsen, 2014; Weindorf et al., 2012a, 2013b; Gardner et al., 2013), the estimation of plant-nutrient elements (Zhu and Weindorf, 2009), the development of pre- 
dictive relationships for soil constituents (Weindorf et al., 2009, 2013b), the identification of soil diagnostic features (Weindorf et al., 2012b), and soil reaction (pH) (Sharma et al., 2014). The exploration of its applications is continually growing in scope and in different environmental and climatic settings. The rapid quantification of elemental contaminants, a benefit offered by PXRF spectrometry, is important in ensuring faster tracking of contaminants, which will facilitate their containment, thus reducing the risk of entry into the food chain. This work is one such effort to extend the application of this tool to semi-arid regions (e.g., the Southern High Plains (SHP) of the United States), which are typically confronted by challenges of extreme drought, wind erosion, soil salinization, etc. In this region lie economically important cities such as Lubbock, which produces close to $25 \%$ of US cotton (USDA-NASS, 2014), and Midland, currently known for intense oil exploration activities. Lubbock's climatic and environmental challenges are typical of those of the SHP and other semi-arid areas of the world (e.g., Spain, parts of northern Africa, and Australia), generally characterized by high-pH (mostly > 7.5) soils and low precipitation $\left(<470 \mathrm{~mm} \mathrm{yr}^{-1}\right)$, which limits soil contaminant leaching, thereby increasing the likelihood of its accumulation in soils. In addition to anthropogenic sources of soil contaminants such as agricultural activities, poor-quality water from the Ogallala Aquifer, which covers almost all the water needs of this area, is also leading to serious environmental challenges (Scanlon et al., 2005).

Lately, growing unrest concerning depleted water quality in the Ogallala Aquifer has also raised concerns regarding the soil quality in irrigated fields and facilities in this region, especially irrigated facilities in urban landscapes such as golf courses because of their unique management practices. Such unique practices include perennial monoculture vegetation, less soil pulverization, and extended irrigation windows. Golf courses are one of the major users of irrigation water per unit area in this region. A typical 18-hole golf facility in the southwestern US region could use an average of $1200 \mathrm{~mm}$ of water annually (USGA, 2012) compared to $600 \mathrm{~mm}$ for fully irrigated cotton in the same region (Snowden et al., 2013). With a rainfall total of approximately $470 \mathrm{~mm} \mathrm{yr}^{-1}$, the majority of the water needed by golf courses comes from groundwater sources. Thus, contaminants carried in the water will be more evident in areas more frequently irrigated (Udeigwe et al., 2013). In addition to contamination from irrigation sources, contaminants in agrochemicals, such as fertilizers which carry traces of heavy metals that may endanger human health (Nziguheba and Smolders, 2008), will also be more evident under managed (irrigated and fertilized) conditions. Unfortunately, information on the extent of contamination, chemistry, and interactions of such contaminants in urban landscape facilities in semi-arid climates is not readily available.

The first approach to designing a remediation program for a polluted site is a proper quantification of the pollutant level and identification of the possible sources. Usually, extensive soil sampling and laborious digestion techniques are required to quantify heavy metal concentration in soils. However, the advent of portable X-ray fluorescence (PXRF) spectrometry and its application to heavy metal detection and quantification in soils can be of immense importance for probing environmental contamination in different landscapes and land uses in semi-arid climates. In fact, several studies (e.g., Ge et al.,1997; Laiho and Perämäki, 2005) have noted that moisture is one factor that must be considered as a possible interference in high-quality in situ PXRF readings; this is a variable with minimal impact in arid regions of west Texas. We hypothesize that differences exist in the level and chemistry of elemental contaminants between managed (irrigated) and non-managed (non-irrigated) zones of golf course facilities in this region, due to limited rainfall and leaching, poor groundwater quality, and the unique management practices of golf courses found in semi-arid climates. As such, the objectives of this study were to apply PXRF spectrometry to the (1) quantification of the differences in the concentration and chemistry (interactions among elements and between elements and soil constituents) of elemental contaminants and (2) examination and source apportionment of these elements among managed and non-managed areas of golf courses in a semi-arid region.

\section{Materials and methods}

\subsection{Study location and site description}

This study was conducted in the city of Lubbock, situated in the western part of Texas $\left(33^{\circ} 34^{\prime} 0^{\prime \prime} \mathrm{N}, 101^{\circ} 53^{\prime} 0^{\prime \prime} \mathrm{W}\right.$; 990 ma.s.l. (USGS, 2014)). Seven golf course facilities, spread throughout Lubbock, each with an average 10-12 ha of irrigated fairways, were selected that met the objectives of this study. The locations of the selected facilities are shown in Fig. 1 and are designated AF, BF, CF, DF, EF, GF, and HF. Each facility has been managed for at least 12 years. Soil types at the study sites included the Amarillo (fine-loamy, mixed, superactive, thermic Aridic Paleustalfs) and Acuff (fine-loamy, mixed, superactive, thermic Aridic Paleustolls) series (Soil Survey Staff, 2014). Managed fairways were generally planted with hybrid Bermuda grass (Cynodon dactylon (L.) Pers. $\times$ C. transvaalensis Burtt-Davy), while nonmanaged areas of the facilities were composed of either bare soil, poorly managed grass cover, or native vegetation and were generally not irrigated.

\subsection{Soil sampling and handling}

Fairways that are consistently irrigated were designated "managed areas", whereas non-irrigated and non-managed adjacent areas of similar soil types were designated "nonmanaged areas". At each facility, a well-managed fairway and an adjacent poorly managed fairway were identified, and 


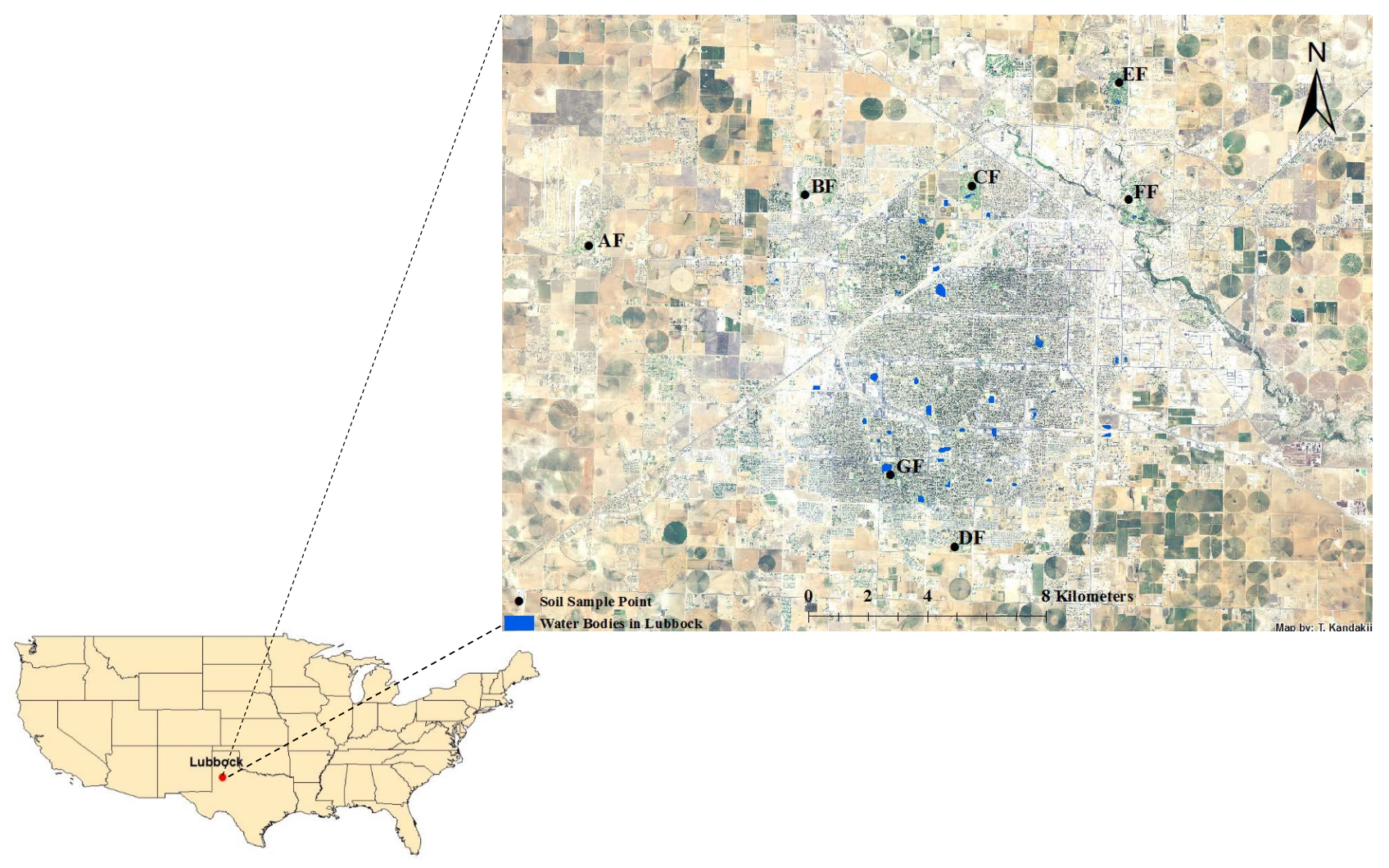

Figure 1. Map showing the seven golf facilities examined in Lubbock, Texas, USA. The facilities are designated AF, BF, CF, DF, EF, FF, and GF

soil samples were collected using a core sampler. In each area, $3-4$ core samples ( $30 \mathrm{~cm}$ deep by $6 \mathrm{~cm}$ wide (diameter)) were randomly collected and then separated into three depths of $0-10,10-20$, and $20-30 \mathrm{~cm}$, which were then combined for each depth to obtain a representative sample. Soil samples were then air-dried, ground, and passed through a $2 \mathrm{~mm}$ sieve. All sampling was conducted in June and July of 2013. All sampling sites were georeferenced using a global positioning system receiver (GPSmap 60CSx, Garmin, Olathe, KS, USA).

\subsection{Soil characterization}

Soil samples were analyzed for electrical conductivity (EC) and $\mathrm{pH}$ in $1: 2$ solid (soil) to water suspension (Rhoades et al., 1996); organic matter (OM) was determined by the modified Walkley and Black method (using sodium dichromate and read on a Gilford unit) (Nelson et al., 1996), and calcium carbonate percentage $\left(\mathrm{CaCO}_{3}\right)$ was determined using the tensimeter method (a modification of the pressure calcimeter approach) (Loeppert and Suarez, 1996; Soil Survey Staff, 1996). Particle size distribution was determined using the hydrometer method (Gee et al., 1986).

\subsection{Elemental quantification: PXRF spectrometry}

Soil samples were scanned using a DP-6000 Delta Premium PXRF spectrometer (Olympus, Waltham, MA, USA) per USEPA Method 6200 (USEPA, 2007). The PXRF instrument is equipped with a $\mathrm{Rh} \mathrm{X}$-ray tube, which is operated at 10 $40 \mathrm{kV}$ with an integrated silicon drift detector $(165 \mathrm{eV})$. The instrument was operated in Soil Mode. This mode consists of three X-ray beams operating sequentially, each set to scan for $30 \mathrm{~s}$ for a total scan time of $90 \mathrm{~s}$. The beams ensure full coverage of elemental detection, with each beam or combination of beams detecting different groups of elements. The calibration of the instrument was conducted before sample analysis using a 316 alloy clip tightly fitted over the aperture. Each soil sample was scanned in triplicate, with the PXRF unit repositioned between scans such that an average value was reported. The elements measured include As (manufacturer's suggested limit of detection: $<5 \mathrm{ppm}), \mathrm{Ca}(<50 \mathrm{ppm}), \mathrm{Cu}$ $(<10 \mathrm{ppm}), \mathrm{Cl}(<200 \mathrm{ppm}), \mathrm{Cr}(<10 \mathrm{ppm}), \mathrm{Fe}(<10 \mathrm{ppm})$, $\mathrm{K}(<50 \mathrm{ppm}), \mathrm{Mn}(<10 \mathrm{ppm}), \mathrm{Ni}(<10 \mathrm{ppm}), \mathrm{Pb}(<5 \mathrm{ppm})$, $\mathrm{S}(<200 \mathrm{ppm})$, and $\mathrm{Zn}(5 \mathrm{ppm})$. Relative percentage differences between two replicates were generally less than 10. Elemental concentration data and the limit of detection (LOD) (3 times the standard error) for each element were obtained and compiled. 


\subsection{Statistical analyses}

Mean values for each location (managed or non-managed) were obtained by using the averages of the three depths given above. All statistical analyses were performed using the Statistical Analysis Software (SAS 9.3, SAS Institute, Cary, NC). Mean differences were examined using PROC GLM. Single and multiple linear regression analyses to establish the relationships among elements and between elements and soil constituents were performed using the PROC REG procedure. Principal component analysis (PCA), used in evaluating potential sources of heavy metals and other trace elements of interest, was performed using PROC FACTOR.

\section{Results and discussions}

\subsection{Fundamental soil chemical properties}

Table 1 summarizes the soil $\mathrm{pH}, \mathrm{OM}, \mathrm{EC}$, and selected nutrient elements in managed and non-managed areas of each investigated facility. Soil $\mathrm{pH}$ was generally $>7.9$ with a small to no difference between managed and non-managed areas, suggesting that $\mathrm{pH}$ was not strongly influenced by management practices. Differences in soil OM and percentage of $\mathrm{CaCO}_{3}$ were noted between the two areas, despite not being significant. The higher soil OM observed in the managed areas could be attributed to higher biomass induced by management practices. Soil EC ( $p<0.05$ in five facilities), $\mathrm{S}$ ( $p<0.05$ in two facilities), and $\mathrm{Cl}(p<0.05$ in five facilities) were consistently higher in the managed areas of facilities examined, indicating the influence of irrigation water quality and fertilization. Total $\mathrm{K}$ and $\mathrm{Ca}$ quantified by PXRF spectrometry, although mostly non-significantly different, tended to be higher in the non-managed areas, in four out of seven and five out of seven facilities for $\mathrm{K}$ and $\mathrm{Ca}$, respectively. One notable finding is that PXRF-measured $\mathrm{Ca}$ predicted over $92 \%(p<0.001)$ of the variability associated with $\mathrm{CaCO}_{3}$. This finding supports those of Zhu and Weindorf (2009) and suggests that this tool can be used to approximate calcite in semi-arid soils.

\subsection{Heavy metals and As}

Findings on heavy metals and As in the managed and nonmanaged areas of each facility are summarized in Table 2 . The majority of the observed differences between managed and non-managed areas were not significant. Copper and $\mathrm{Zn}$ were higher in the managed areas of five facilities (AF, CF, $\mathrm{DF}, \mathrm{FF}$, and $\mathrm{GF}$ ), while $\mathrm{As}, \mathrm{Cr}$, and $\mathrm{Pb}$ were higher in the managed areas of four of the facilities (AF, DF, FF, and GF) (Table 2). Nickel and Mn were higher in the managed areas of three of the facilities (AF, CF, and GF); the same was the case for Fe for AF, DF, and GF (Table 2). Although not significant, the findings suggest a degree of association among the metals. These associations show evidence of the interac- tions of these elementals with other soil constituents, such as clay, $\mathrm{CaCO}_{3}$, and $\mathrm{OM}$, and will be further examined in Sect. 3.3. Among facilities, the managed areas of GF were higher in all the elements examined ( $p<0.05$ for $\mathrm{Cr}, \mathrm{Mn}$, and $\mathrm{Fe})$. The higher concentration of these elements in the managed areas of the GF facility could be attributed to the mean clay content (46\%) at this site, which was the highest among all the managed sites. As will be discussed later (Sect. 3.3), clay exhibited a significant positive interaction with all the examined elements, a finding that has been extensively documented (Sparks, 2003; Sposito, 2008; Eze et al., 2010).

The distribution of each element between managed and non-managed areas was further examined within the depths of $0-10,10-20$, and $20-30 \mathrm{~cm}$. Thus, all the managed areas were grouped and compared with the non-managed areas at each depth for each of the elements. However, there was no consistent and substantial difference between managed and non-managed areas within depths (data not shown).

\subsection{Chemistry of elements: interactions among elements and between elements and soil constituents}

Although interactions among elements and between elements and soil constituents have been widely documented (Yu et al., 2001; Biasioli et al., 2006; Micó et al., 2006; Jørgensen and Jensen, 2009; Eze et al., 2010), extending these findings to different environmental and climatic settings can be misleading due to soil heterogeneity. Such interactions can vary with environmental and climatic variables as well as with the presence and proportion of other soil constituents. As a result, the site-specific evaluation of these interactions is often an invaluable resource for the source allocation of pollutant and remediation purposes. The summary of the correlations among the examined elements when all data points $(n=42)$ from managed and non-managed areas were considered is presented in Table 3 . The strongest relationships were between $\mathrm{Fe}$ and $\mathrm{Cr}(R=0.91, p<0.001)$, Mn $(R=0.89, p<0.001)$, Ni $(R=0.82, p<0.001)$, and As $(R=0.86, p<0.001)$, as well as between $\mathrm{Cu}$ and $\mathrm{Zn}$ $(R=0.82, p<0.0001)$ and between $\mathrm{As}$ and $\mathrm{Cr}(R=0.87$, $p<0.001)$. The weakest relationships were between $\mathrm{Ni}$ and $\mathrm{Zn}(R=0.34, p<0.028)$ and between $\mathrm{Ni}$ and $\mathrm{Pb}(R=0.40$, $p<0.009)$. One striking finding here is that, when the managed and non-managed sites were analyzed separately and compared, the strengths of these relationships were generally greater in the non-managed areas (Table 4). The most notable differences were between $\mathrm{Cr}$ and $\mathrm{Zn}(R$ of 0.88 vs. 0.35 ), $\mathrm{Cr}$ and $\mathrm{Pb}$ ( $R$ of 0.83 vs. 0.36 ), $\mathrm{Pb}$ and $\mathrm{Mn}$ ( $R$ of 0.78 vs. 0.46$), \mathrm{Pb}$ and $\mathrm{Ni}$ ( $R$ of 0.61 vs. 0.17 ), and $\mathrm{Pb}$ and $\mathrm{As}$ ( $R$ of 0.80 vs. 0.24 ). These differences can be attributed to the influence of anthropogenic sources in the managed areas, which possibly altered the natural background relationships among these elements. Interactions among metals have been documented in different landscapes, land uses, and environ- 
Table 1. Summary of selected soil chemical and physical properties and of nutrient elements in the managed and non-managed areas of the golf course facilities examined in Lubbock, Texas, USA*.

\begin{tabular}{|c|c|c|c|c|c|c|c|c|c|c|}
\hline \multirow[t]{2}{*}{ Golf facility } & \multirow[t]{2}{*}{ Management } & \multirow[t]{2}{*}{$\mathrm{pH}$} & OM & $\mathrm{CaCO}_{3}$ & \multirow{2}{*}{$\begin{array}{l}\mathrm{EC} \\
\mu \mathrm{scm}^{-1}\end{array}$} & $\mathrm{~S}$ & $\mathrm{Cl}$ & $\mathrm{K}$ & $\mathrm{Ca}$ & \multirow{2}{*}{$\begin{array}{l}\text { Clay } \\
\%\end{array}$} \\
\hline & & & \multicolumn{2}{|c|}{$\%$} & & \multicolumn{4}{|c|}{$\mathrm{mg} \mathrm{kg}^{-1}$} & \\
\hline \multirow[t]{2}{*}{$\mathrm{AF}$} & M & $8.2 \mathrm{a}$ & $1.5 \mathrm{a}$ & $1.1 \mathrm{a}$ & $445 a$ & $1804 a$ & $145 \mathrm{a}$ & $11729 a$ & $9654 a$ & $21 \mathrm{a}$ \\
\hline & $\mathrm{N}$ & $8.1 \mathrm{a}$ & $0.7 \mathrm{a}$ & $0.2 b$ & $199 b$ & $1287 \mathrm{a}$ & $133 a$ & $11275 a$ & $5098 \mathrm{a}$ & $21 \mathrm{a}$ \\
\hline \multirow[t]{2}{*}{$\mathrm{BF}$} & M & $8.3 b$ & $1.0 \mathrm{a}$ & $8.8 \mathrm{a}$ & $1561 \mathrm{a}$ & $2542 \mathrm{a}$ & $677 \mathrm{a}$ & $14700 \mathrm{a}$ & $52738 \mathrm{a}$ & $30 \mathrm{a}$ \\
\hline & $\mathrm{N}$ & $8.4 \mathrm{a}$ & $0.5 \mathrm{a}$ & $4.5 \mathrm{a}$ & $417 b$ & $1467 b$ & $78.0 \mathrm{~b}$ & $15915 a$ & $33205 a$ & $37 \mathrm{a}$ \\
\hline \multirow[t]{2}{*}{$\mathrm{CF}$} & M & $8.2 b$ & $1.2 \mathrm{a}$ & $1.9 \mathrm{a}$ & $1187 \mathrm{a}$ & $1997 a$ & $582 \mathrm{a}$ & $14172 b$ & $10137 \mathrm{a}$ & $29 a$ \\
\hline & $\mathrm{N}$ & $8.5 \mathrm{a}$ & $0.5 \mathrm{a}$ & $1.2 \mathrm{a}$ & $219 b$ & $1273 b$ & $0.0 \mathrm{~b}$ & $15800 \mathrm{a}$ & $10233 a$ & $29 \mathrm{a}$ \\
\hline \multirow[t]{2}{*}{$\mathrm{DF}$} & M & $8.6 \mathrm{a}$ & $0.8 \mathrm{a}$ & $0.5 \mathrm{a}$ & $426 \mathrm{a}$ & $1354 a$ & $265 a$ & $10502 \mathrm{a}$ & $5409 a$ & $20 \mathrm{a}$ \\
\hline & $\mathrm{N}$ & $8.6 \mathrm{a}$ & $0.3 \mathrm{a}$ & $0.7 \mathrm{a}$ & $221 b$ & $1179 a$ & $154 b$ & $9310 \mathrm{a}$ & $10796 a$ & $17 \mathrm{a}$ \\
\hline \multirow[t]{2}{*}{$\mathrm{EF}$} & M & $8.2 \mathrm{a}$ & $1.1 \mathrm{a}$ & $4.6 \mathrm{a}$ & $815 a$ & $2046 a$ & $342 \mathrm{a}$ & $11990 \mathrm{~b}$ & $28090 \mathrm{a}$ & $23 b$ \\
\hline & $\mathrm{N}$ & $7.9 \mathrm{a}$ & $1.3 \mathrm{a}$ & $6.4 \mathrm{a}$ & $699 a$ & $1910 \mathrm{a}$ & $73.7 b$ & $18594 a$ & $36222 a$ & $46 a$ \\
\hline \multirow[t]{2}{*}{$\mathrm{FF}$} & M & $8.0 \mathrm{a}$ & $1.3 \mathrm{a}$ & $0.7 \mathrm{a}$ & $991 \mathrm{a}$ & $2015 a$ & $521 \mathrm{a}$ & $13119 a$ & $13335 \mathrm{a}$ & $22 \mathrm{a}$ \\
\hline & $\mathrm{N}$ & $8.1 \mathrm{~b}$ & $0.9 \mathrm{a}$ & $1.6 \mathrm{a}$ & $605 a$ & $1507 a$ & $337 \mathrm{a}$ & $14501 a$ & $16051 \mathrm{a}$ & $27 \mathrm{a}$ \\
\hline \multirow[t]{2}{*}{ GF } & M & $8.1 \mathrm{a}$ & $1.5 \mathrm{a}$ & $4.2 \mathrm{a}$ & $810 \mathrm{a}$ & $1874 a$ & $293 a$ & $20820 \mathrm{a}$ & $32476 a$ & $46 a$ \\
\hline & $\mathrm{N}$ & $8.3 \mathrm{a}$ & $0.7 \mathrm{a}$ & $4.7 \mathrm{a}$ & $409 \mathrm{~b}$ & $1318 \mathrm{a}$ & $95.7 \mathrm{~b}$ & $15808 b$ & $32575 a$ & $36 b$ \\
\hline
\end{tabular}

${ }^{*} \mathrm{M}$ - managed area; $\mathrm{N}$ - non-managed area; $\mathrm{CaCO}_{3}$ - calcium carbonate equivalent; $\mathrm{EC}$ - soil electrical conductivity. Mean values in a column within a golf course with the same letter are not statistically different (Fisher's LSD, $\alpha=0.05$ ).

Table 2. Summary of heavy metals and As quantified using the PXRF spectrometer in the managed and non-managed areas of the golf course facilities in Lubbock, Texas, USA*.

\begin{tabular}{|c|c|c|c|c|c|c|c|c|c|}
\hline \multirow[t]{2}{*}{ Golf facility } & \multirow[t]{2}{*}{ Management } & As & $\mathrm{Cr}$ & $\mathrm{Pb}$ & $\mathrm{Ni}$ & $\mathrm{Cu}$ & $\mathrm{Zn}$ & $\mathrm{Mn}$ & $\mathrm{Fe}$ \\
\hline & & \multicolumn{8}{|c|}{$\mathrm{mg} \mathrm{kg}^{-1}$} \\
\hline \multirow[t]{2}{*}{$\mathrm{AF}$} & M & $4.9 \mathrm{a}$ & $22.7 \mathrm{a}$ & $13.7 \mathrm{a}$ & $26.3 \mathrm{a}$ & $11.5 \mathrm{a}$ & $36.6 \mathrm{a}$ & $205 a$ & $10638 \mathrm{a}$ \\
\hline & $\mathrm{N}$ & $4.07 \mathrm{a}$ & $19.3 \mathrm{a}$ & $10.8 \mathrm{a}$ & $25.0 \mathrm{a}$ & $8.70 \mathrm{a}$ & $24.8 \mathrm{a}$ & $157 \mathrm{a}$ & $8985 a$ \\
\hline \multirow[t]{2}{*}{$\mathrm{BF}$} & M & $6.80 \mathrm{a}$ & $25.3 \mathrm{a}$ & $12.5 \mathrm{a}$ & $31.0 \mathrm{a}$ & $11.4 \mathrm{~b}$ & $39.3 \mathrm{a}$ & $175 b$ & $11428 b$ \\
\hline & $\mathrm{N}$ & $7.90 \mathrm{a}$ & $33.3 \mathrm{a}$ & $13.2 \mathrm{a}$ & $37.0 \mathrm{a}$ & $15.2 \mathrm{a}$ & $40.7 \mathrm{a}$ & $217 \mathrm{a}$ & $15493 a$ \\
\hline \multirow[t]{2}{*}{$\mathrm{CF}$} & M & $5.70 \mathrm{~b}$ & $29.7 \mathrm{a}$ & $13.4 \mathrm{~b}$ & $34.7 \mathrm{a}$ & $16.1 \mathrm{a}$ & $74.0 \mathrm{a}$ & $279 a$ & $12917 b$ \\
\hline & $\mathrm{N}$ & $7.00 \mathrm{a}$ & $34.3 \mathrm{a}$ & $17.2 \mathrm{a}$ & $32.7 \mathrm{a}$ & $14.1 \mathrm{a}$ & $41.2 \mathrm{a}$ & $271 \mathrm{a}$ & $14463 a$ \\
\hline \multirow[t]{2}{*}{$\mathrm{DF}$} & M & $4.47 \mathrm{a}$ & $16.7 \mathrm{a}$ & $8.67 \mathrm{a}$ & $19.3 \mathrm{a}$ & $9.37 \mathrm{a}$ & $26.5 \mathrm{a}$ & $126 \mathrm{a}$ & $9322 a$ \\
\hline & $\mathrm{N}$ & $4.10 \mathrm{a}$ & $15.3 \mathrm{a}$ & $7.93 \mathrm{a}$ & $26.0 \mathrm{a}$ & $8.77 \mathrm{a}$ & $19.3 \mathrm{a}$ & $154 \mathrm{a}$ & $7356 a$ \\
\hline \multirow[t]{2}{*}{$\mathrm{EF}$} & M & $4.70 \mathrm{a}$ & $22.0 \mathrm{~b}$ & $20.1 b$ & $30.7 b$ & $11.2 \mathrm{~b}$ & $55.5 \mathrm{a}$ & $184 b$ & $9297 b$ \\
\hline & $\mathrm{N}$ & $9.83 \mathrm{a}$ & $48.0 \mathrm{a}$ & $43.6 \mathrm{a}$ & $45.7 \mathrm{a}$ & $21.1 \mathrm{a}$ & $83.0 \mathrm{a}$ & $346 a$ & $20963 \mathrm{a}$ \\
\hline \multirow[t]{2}{*}{ FF } & M & $4.70 \mathrm{a}$ & $28.0 \mathrm{a}$ & $26.3 \mathrm{a}$ & $25.0 \mathrm{a}$ & $20.6 a$ & $74.0 \mathrm{a}$ & $202 a$ & $10676 a$ \\
\hline & $\mathrm{N}$ & $4.67 \mathrm{a}$ & $23.3 b$ & $14.3 \mathrm{a}$ & $28.0 \mathrm{a}$ & $12.2 \mathrm{a}$ & $37.7 \mathrm{a}$ & $225 \mathrm{a}$ & $11280 \mathrm{a}$ \\
\hline \multirow[t]{2}{*}{ GF } & $\mathrm{M}$ & $10.47 \mathrm{a}$ & $48.3 \mathrm{a}$ & $21.3 \mathrm{a}$ & $45.7 \mathrm{a}$ & $22.3 a$ & $76.7 \mathrm{a}$ & $425 a$ & $22734 a$ \\
\hline & $\mathrm{N}$ & $5.77 \mathrm{a}$ & $29.7 b$ & $15.6 \mathrm{a}$ & $38.0 \mathrm{a}$ & $15.6 \mathrm{a}$ & $42.7 \mathrm{a}$ & $239 b$ & $14226 b$ \\
\hline
\end{tabular}

* $\mathrm{M}$ - managed area; $\mathrm{N}-$ non-managed area.

Mean values in a column within a golf course with the same letter are not statistically different (Fisher's LSD, $\alpha=0.05$ ).

mental media (Tkalin et al., 1996; Li et al., 2000; Facchinelli, 2001; Dragovic et al., 2008; Eze et al., 2010), although the strengths of these interactions often vary. Such variability necessitates the need for site-specific investigations, as presented in this study.

The interactions between the examined elements and the soil constituents, such as carbonates, $\mathrm{OM}$, clay, and $\mathrm{pH}$, are 
Table 3. Correlation matrix of the elements in all soil samples (managed and non-managed) from the golf course facilities examined in Lubbock, Texas, USA $(n=42)$.

\begin{tabular}{lllllllll}
\hline & $\mathrm{Cr}$ & $\mathrm{Mn}$ & $\mathrm{Fe}$ & $\mathrm{Ni}$ & $\mathrm{Cu}$ & $\mathrm{Zn}$ & $\mathrm{As}$ & $\mathrm{Pb}$ \\
\hline $\mathrm{Cr}$ & & & & & & & & \\
$\mathrm{Mn}$ & $0.85^{\mathrm{c}}$ & & & & & & & \\
$\mathrm{Fe}$ & $0.91^{\mathrm{c}}$ & $0.89^{\mathrm{c}}$ & & & & & & \\
$\mathrm{Ni}$ & $0.77^{\mathrm{c}}$ & $0.68^{\mathrm{c}}$ & $0.82^{\mathrm{c}}$ & & & & & \\
$\mathrm{Cu}$ & $0.72^{\mathrm{c}}$ & $0.75^{\mathrm{c}}$ & $0.78^{\mathrm{c}}$ & $0.60^{\mathrm{c}}$ & & & & \\
$\mathrm{Zn}$ & $0.50^{\mathrm{c}}$ & $0.65^{\mathrm{c}}$ & $0.56^{\mathrm{c}}$ & $0.34^{\mathrm{a}}$ & $0.82^{\mathrm{c}}$ & & & \\
$\mathrm{As}$ & $0.87^{\mathrm{c}}$ & $0.77^{\mathrm{c}}$ & $0.86^{\mathrm{c}}$ & $0.71^{\mathrm{c}}$ & $0.60^{\mathrm{c}}$ & $0.48^{\mathrm{b}}$ & & \\
$\mathrm{Pb}$ & $0.65^{\mathrm{c}}$ & $0.59^{\mathrm{c}}$ & $0.57^{\mathrm{c}}$ & $0.40^{\mathrm{b}}$ & $0.66^{\mathrm{c}}$ & $0.68^{\mathrm{c}}$ & $0.58^{\mathrm{c}}$ & \\
\hline
\end{tabular}

${ }^{\text {a }}$ Significant at 0.05 probability level; ${ }^{\mathrm{b}}$ significant at 0.01 probability level;

c significant at 0.001 probability level.

Table 4. Correlation matrix of the elements in soils for managed (bold) and non-managed sites of the golf course facilities examined in Lubbock, Texas, USA $(n=21)$.

\begin{tabular}{|c|c|c|c|c|c|c|c|c|c|}
\hline & & \multicolumn{8}{|c|}{ Managed } \\
\hline & & $\mathrm{Cr}$ & Mn & $\mathrm{Fe}$ & $\mathrm{Ni}$ & $\mathrm{Cu}$ & $\mathrm{Zn}$ & As & $\mathrm{Pb}$ \\
\hline \multirow[t]{8}{*}{ Non-managed } & $\mathrm{Cr}$ & & $0.86^{\mathrm{c}}$ & $0.92^{\mathrm{c}}$ & $0.79^{c}$ & $0.69^{c}$ & 0.35 & $0.83^{c}$ & 0.36 \\
\hline & $\mathrm{Mn}$ & $0.87^{\mathrm{c}}$ & & $0.94^{\mathrm{c}}$ & $0.73^{c}$ & $0.76^{\mathrm{c}}$ & $0.61^{b}$ & $0.81^{\mathrm{c}}$ & $0.46^{\mathrm{a}}$ \\
\hline & $\mathrm{Fe}$ & $0.90^{\mathrm{c}}$ & $0.84^{\mathrm{c}}$ & & $0.76^{\mathrm{c}}$ & $0.69^{c}$ & $0.44^{\mathrm{a}}$ & $0.93^{c}$ & 0.33 \\
\hline & $\mathrm{Ni}$ & $0.76^{\mathrm{c}}$ & $0.63^{\mathrm{b}}$ & $0.90^{\mathrm{c}}$ & & 0.44 & 0.20 & $0.76^{\mathrm{c}}$ & 0.17 \\
\hline & $\mathrm{Cu}$ & $0.82^{\mathrm{c}}$ & $0.74^{\mathrm{b}}$ & $0.95^{\mathrm{c}}$ & $0.94^{\mathrm{c}}$ & & $0.81^{c}$ & $0.57^{b}$ & $0.75^{c}$ \\
\hline & $\mathrm{Zn}$ & $0.88^{\mathrm{c}}$ & $0.84^{\mathrm{c}}$ & $0.92^{\mathrm{c}}$ & $0.81^{\mathrm{c}}$ & $0.89^{\mathrm{c}}$ & & 0.36 & $0.69^{c}$ \\
\hline & As & $0.90^{\mathrm{c}}$ & $0.74^{\mathrm{c}}$ & $0.80^{\mathrm{c}}$ & $0.66^{\mathrm{b}}$ & $0.67^{\mathrm{c}}$ & $0.78^{\mathrm{c}}$ & & 0.24 \\
\hline & $\mathrm{Pb}$ & $0.83^{\mathrm{c}}$ & $0.78^{\mathrm{c}}$ & $0.75^{\mathrm{c}}$ & $0.61^{\mathrm{b}}$ & $0.70^{\mathrm{c}}$ & $0.92^{\mathrm{c}}$ & $0.80^{\mathrm{c}}$ & \\
\hline
\end{tabular}

${ }^{a}$ Significant at 0.05 probability level; ${ }^{\mathrm{b}}$ significant at 0.01 probability level; ${ }^{\mathrm{c}}$ significant at 0.001 probability level.

summarized for all data points (managed and non-managed) in Table 5. Of interest, with the exception of $\mathrm{Zn}$, clay significantly $(R>0.86, p<0.001)$ controls the distribution of these elements, an interaction that has been documented previously (Bradl, 2004; Sparks, 2003). This association is partly attributed to the abundance of negatively charged sites and high surface area created by clay minerals and, thus, high adsorption capacity for metals (Sparks, 2003; Sposito, 2008). Among other soil constituents, significant positive correlations were also observed between OM on the one hand and $\mathrm{Cu}, \mathrm{Pb}, \mathrm{Mn}$, and $\mathrm{Zn}$ on the other $(R=0.40-0.70, p<0.01)$ as well as between $\mathrm{CaCO}_{3}$ on the one hand and $\mathrm{Ni}$ and $\mathrm{As}$ on the other $(R>0.41-0.42, p<0.01)$ (Table 5). Soil OM contains functional groups such as enol, phenol, and carboxyl, which in their deprotonated forms have a high affinity for metal ions (Sparks, 2003; Sposito, 2008). Also, humic substances form a strong complex with clay, which will enhance its interaction with metal ions (Evangelou, 1998), explaining some of the strong OM-clay and OM-metal interactions observed (Table 6). One notable finding was that all the elements, with the exception of $\mathrm{Ni}$, showed a significant negative relationship with $\mathrm{pH}(R=-0.31$ to $-0.62, p<0.01)$, an indication that metal retention in these soils decreases with
$\mathrm{pH}$ (within the $\mathrm{pH}$ range of 7.7-8.8) (Table 5). Metal adsorption generally increases within a narrow $\mathrm{pH}$ range (adsorption edge) where sorption is maximized (Sposito, 2008). As evidenced by this study, the $\mathrm{pH}$ range of 7.7-8.8 observed for these soils could be outside the adsorption edge for the examined elements, thus resulting in the negative relationships observed between these elements and $\mathrm{pH}$. Interestingly, when the managed and non-managed sites were analyzed separately, it was observed that the strengths of these relationships (i.e., elements on the one hand vs. $\mathrm{OM}, \mathrm{CaCO}_{3}$, and clay on the other) were notably higher in the non-managed areas compared to the managed areas (Table 6). The major contrast here was the relationship between the percentage of $\mathrm{CaCO}_{3}$ and the elements, which was highly significant ( $R=0.51-0.75, p<0.01)$ for all the elements in the nonmanaged area but almost nonexistent in the managed area. These strong relationships could be an indication that these elements are naturally bound to carbonates in the semi-arid soils of the SHP, a situation not evident in the managed areas because of potential anthropogenic influences which can alter these natural background relationships.

Information on these interactions within urban landscapes in this region has not been widely documented, and, as a re- 
Table 5. Correlation coefficients of the relationships between elements and other soil constituents for all soil samples (managed and non-managed) from the golf course facilities examined in Lubbock, Texas, USA $(n=42)$.

\begin{tabular}{lrrrr}
\hline & $\mathrm{OM}$ & $\mathrm{CaCO}_{3}$ & Clay & $\mathrm{pH}$ \\
\hline $\mathrm{Cr}$ & 0.24 & 0.37 & $0.86^{\mathrm{c}}$ & $-0.43^{\mathrm{b}}$ \\
$\mathrm{Mn}$ & $0.40^{\mathrm{b}}$ & 0.18 & $0.75^{\mathrm{c}}$ & $-0.50^{\mathrm{c}}$ \\
$\mathrm{Fe}$ & 0.25 & $0.32^{\mathrm{a}}$ & $0.91^{\mathrm{c}}$ & $-0.38^{\mathrm{b}}$ \\
$\mathrm{Ni}$ & -0.08 & $0.42^{\mathrm{b}}$ & $0.88^{\mathrm{c}}$ & -0.15 \\
$\mathrm{Cu}$ & $0.43^{\mathrm{b}}$ & 0.20 & $0.65^{\mathrm{c}}$ & $-0.50^{\mathrm{c}}$ \\
$\mathrm{Zn}$ & $0.70^{\mathrm{c}}$ & 0.21 & $0.39^{\mathrm{a}}$ & $-0.61^{\mathrm{c}}$ \\
$\mathrm{As}$ & 0.30 & $0.41^{\mathrm{b}}$ & $0.79^{\mathrm{c}}$ & $-0.31^{\mathrm{a}}$ \\
$\mathrm{Pb}$ & $0.49^{\mathrm{c}}$ & 0.29 & $0.46^{\mathrm{b}}$ & $-0.63^{\mathrm{c}}$ \\
\hline
\end{tabular}

${ }^{\text {a }}$ Significant at 0.05 probability level; ${ }^{\mathrm{b}}$ significant at 0.01 probability level; ${ }^{\mathrm{c}}$ significant at 0.001 probability level.

sult, reference materials on this subject area are scarce. As will be shown later (Sect. 3.4), these relationships are useful in pollutant source allocation (Facchinelli, 2001; Yu et al., 2001; Jørgensen and Jensen, 2009; Eze et al., 2010) and for environmental remediation purposes (García-Sánchez et al., 1999; Hartley and Lepp, 2008; Kabata-Pendias, 2010). For instance, the strong affinity of Fe for As as evidenced by the findings here is often characterized as an inner-sphere complexation (Sparks, 2003; Sposito, 2008). This suggests that Fe-containing materials can be used to immobilize As in these soils. The same can also be said for the other heavy metals, such as $\mathrm{Cr}$ and $\mathrm{Ni}$, which also exhibited strong interaction with Fe. Typically, heavy metal fractionation identifies different pools of metals, such as easily exchangeable $\mathrm{Fe}-$ or Mn-oxide-bound fraction, carbonate-bound fraction, and OM-bound fraction (Sposito et al., 1982; Tack and Verloo, 1995; McLaren and Clucas, 2001). Thus, the strong relationship observed between $\mathrm{Fe} / \mathrm{Mn}$ and the heavy metals, $\mathrm{Cr}$ and $\mathrm{Ni}$, could suggest that a significant portion of these metals are in the $\mathrm{Fe}$ - and $\mathrm{Mn}$-oxide/bound fraction at the examined sites. Likewise, the stronger relationships between the examined elements (heavy metals and $\mathrm{As}$ ) and $\mathrm{CaCO}_{3}$ in the non-managed areas suggest that a significant pool of these elements are bound to carbonates. In summary, the examination of the chemistry and interactions among elements and between elements and soil constituents indicated that the nature and strengths of the relationships vary within managed and non-managed areas of the golf course facilities examined. This can be attributed to management practices such as irrigation, fertilization, the addition of other soil amendments and agrochemicals, and surface soil modifications, which constitute anthropogenic influences that can temporally alter the natural background relationships among these elements and, thus, their chemistry.
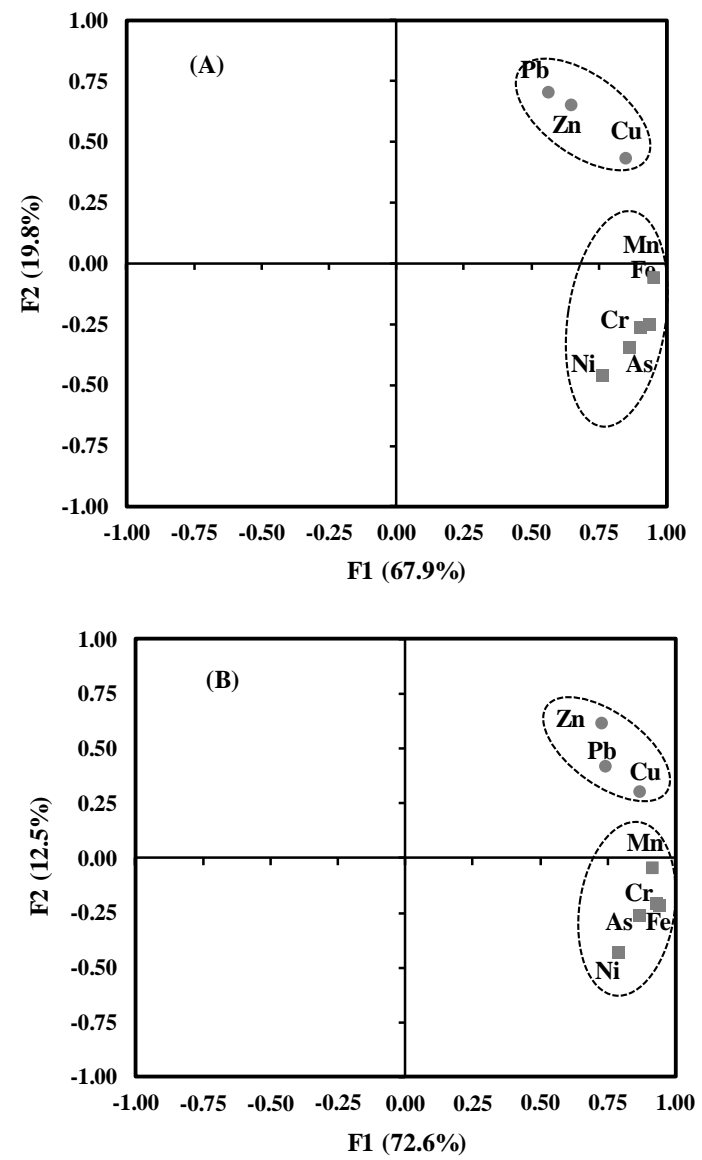

Figure 2. Principal component analysis loading plots of elements in soils of the golf course facilities in Lubbock, Texas, USA, for (a) managed site only and (b) managed and non-managed sites combined. Only two factors were extracted and interpreted.

\subsection{Source apportionment}

With the findings obtained from the PXRF quantification of the heavy metals and As, an attempt was made to define the sources of these contaminants at the examined facilities. Pollutant source apportionment was conducted individually within managed (irrigated) and non-managed (non-irrigated) areas, as well as in both areas combined, with the aid of PCA and the correlation matrix discussed in Sect. 3.3. The PCA is a tool commonly used in geochemical applications to define pollutant sources, mostly natural vs. anthropogenic sources (Facchinelli, 2001; Micó et al., 2006; Eze et al., 2010).

The PCA loading plots of elements examined at the seven golf facilities are presented in Fig. 2. The critical eigenvalue of 1 was used for each analysis. For the managed site, only the first two components with an eigenvalue $>1$ were retained. The elements were grouped into a two-component model that accounted for $88 \%$ of the variation. For the managed (irrigated) areas $(n=21)$, it was evident that As, $\mathrm{Cr}$, $\mathrm{Fe}, \mathrm{Mn}$, and $\mathrm{Ni}$ were associated with the $\mathrm{F} 1$ component, 
Table 6. Correlation coefficients of the relationships between elements and other soil constituents at managed and non-managed sites of the golf course facilities in Lubbock, Texas, USA $(n=21)$.

\begin{tabular}{|c|c|c|c|c|c|c|c|c|}
\hline & \multicolumn{4}{|c|}{ Managed } & \multicolumn{4}{|c|}{ Non-managed } \\
\hline & $\mathrm{OM}$ & $\mathrm{CaCO}_{3}$ & Clay & $\mathrm{pH}$ & $\mathrm{OM}$ & $\mathrm{CaCO}_{3}$ & Clay & $\mathrm{pH}$ \\
\hline $\mathrm{Cr}$ & 0.15 & 0.17 & $0.88^{\mathrm{c}}$ & $-0.45^{\mathrm{a}}$ & $0.53^{\mathrm{a}}$ & $0.69^{\mathrm{c}}$ & $0.86^{\mathrm{c}}$ & $-0.44^{b}$ \\
\hline $\mathrm{Mn}$ & 0.41 & 0.02 & $0.79^{\mathrm{c}}$ & $-0.53^{b}$ & $0.49^{\mathrm{a}}$ & $0.51^{\mathrm{a}}$ & $0.74^{\mathrm{c}}$ & $-0.48^{\mathrm{a}}$ \\
\hline $\mathrm{Fe}$ & 0.28 & 0.11 & $0.88^{\mathrm{c}}$ & -0.39 & 0.37 & $0.70^{\mathrm{c}}$ & $0.95^{\mathrm{c}}$ & -0.39 \\
\hline $\mathrm{Ni}$ & -0.13 & 0.28 & $0.83^{\mathrm{c}}$ & -0.10 & 0.18 & $0.74^{\mathrm{c}}$ & $0.93^{\mathrm{c}}$ & -0.26 \\
\hline $\mathrm{Cu}$ & $0.47^{\mathrm{a}}$ & -0.06 & $0.50^{\mathrm{a}}$ & $-0.63^{\mathrm{b}}$ & 0.30 & $0.72^{\mathrm{c}}$ & $0.94^{\mathrm{c}}$ & -0.31 \\
\hline $\mathrm{Zn}$ & $0.69^{\mathrm{c}}$ & -0.02 & 0.23 & $-0.65^{\mathrm{b}}$ & $0.65^{\mathrm{b}}$ & $0.75^{\mathrm{c}}$ & $0.85^{\mathrm{c}}$ & $-0.58^{\mathrm{b}}$ \\
\hline As & 0.24 & 0.22 & $0.85^{\mathrm{c}}$ & -0.32 & $0.53^{\mathrm{a}}$ & $0.72^{\mathrm{c}}$ & $0.75^{\mathrm{c}}$ & -0.33 \\
\hline $\mathrm{Pb}$ & $0.48^{\mathrm{a}}$ & -0.08 & 0.14 & $-0.70^{\mathrm{c}}$ & $0.79^{c}$ & $0.69^{c}$ & $0.66^{\mathrm{b}}$ & $-0.64^{b}$ \\
\hline
\end{tabular}

${ }^{a}$ Significant at 0.05 probability level; ${ }^{\mathrm{b}}$ significant at 0.01 probability level; ${ }^{\mathrm{c}}$ significant at 0.001 probability level.

while $\mathrm{Cu}, \mathrm{Pb}$, and $\mathrm{Zn}$ were associated with the F2 component. These associations indicated two different possible pollutant sources. The strong positive relationships $(R=0.76-$ $0.94, p<0.001)$ observed between $\mathrm{Fe}$ and the rest of the F1 elements at the managed site (Table 4), an association often used to distinguish natural levels of trace elements from anthropogenic ones (Facchinelli, 2001; Micó et al., 2006; Eze et al., 2010), suggest that the F1 component (As, Cr, $\mathrm{Fe}, \mathrm{Mn}$, and $\mathrm{Ni}$ ) could be of lithogenic origin. This implies that the concentrations of the elements are probably controlled by soil parent materials. Thus, the $\mathrm{F} 2$ component $(\mathrm{Cu}$, $\mathrm{Pb}$, and $\mathrm{Zn}$ ) is possibly due to an anthropogenic influence (e.g., fertilization). A finding of major significance was that for the non-managed sites $(n=21)$, using the eigenvalue of 1 , only one factor explaining $83 \%$ of the variation was extracted. This finding suggests that the examined elements at the non-managed sites could be due to one source, which is possibly lithogenic. This is a significant finding that supports the hypothesis that management practices can be a potential source of pollutant inputs at these facilities. Furthermore, PCA of the elemental composition of soils from the combined sites (managed and non-managed) extracted two components, $\mathrm{F} 1$ (As, $\mathrm{Cr}, \mathrm{Fe}, \mathrm{Mn}$, and $\mathrm{Ni}$ ) and $\mathrm{F} 2(\mathrm{Cu}, \mathrm{Pb}$, and $\mathrm{Zn}$ ) that explained $85 \%$, a finding similar to that of the managed site, suggesting that overall, background contaminant levels within the entire study area are affected by anthropogenic influences. The total elemental concentration values suggested that the concentrations of the commonly cited heavy metals $(\mathrm{Cr}, \mathrm{Cu}, \mathrm{Ni}$, and $\mathrm{Pb})$ in the soils at these facilities were within the maximum permissible concentration (MPC) in soils set by the United State Environmental Protection Agency (USEPA) and the European Commission (Kabata-Pendias, 2010; Selinus et al., 2013).

\section{Conclusions}

The identification and quantification of possible sources of environmental contaminants are often the first conscious steps taken toward any environmental protection effort. This work extends the application of PXRF spectrometry to the rapid probing of potential elemental contaminants in the semi-arid soils of the SHP, USA, an area confronted by complex environmental challenges. It was hypothesized that limited rainfall and leaching, poor groundwater quality, and unique management practices can affect the concentration, chemistry, and sources of contaminants in urban landscape facilities, such as golf courses, in a semi-arid climate. Although the investigation of heavy metals $(\mathrm{Cr}, \mathrm{Pb}, \mathrm{Ni}, \mathrm{Cu}$, $\mathrm{Mn}, \mathrm{Fe}$, and $\mathrm{Zn}$ ) and As revealed few differences between the managed and non-managed areas of these facilities, findings do, however, show possible associations among elements. Strong relationships and interactions were observed among the elements examined and between elements and soil constituents such as clay, $\mathrm{CaCO}_{3}$, and $\mathrm{OM}$ contents, as well as $\mathrm{pH}$. Interestingly, the strengths of these relationships were mostly higher in the non-managed area, an indication of the alteration of the chemistry of these elements by anthropogenic influences. Evidence gathered from PCA and correlation analyses within the managed area suggested that As, $\mathrm{Cr}, \mathrm{Fe}, \mathrm{Mn}$, and $\mathrm{Ni}$ could be of lithogenic origin, while $\mathrm{Cu}$, $\mathrm{Pb}$, and $\mathrm{Zn}$ could possibly have anthropogenic influences. At the non-managed sites, only one source of contaminant, possibly lithogenic, was identified. Most of the heavy metals examined at the facilities were within the MPC set by the USEPA and European Commission. The findings help to understand the interactions of soil contaminants in the urban landscape in this semi-arid region, which is currently an area of environmental research focus, and they provide background information for future studies and remediation programs. Findings could also be extended to other semi-arid and arid regions of the world. 


\section{The Supplement related to this article is available online at doi:10.5194/se-6-415-2015-supplement.}

Author contributions. T. K. Udeigwe and J. Young initiated the study. T. Kandakji assisted in field and laboratory activities. M. A. Mahmoud and H. M. Stietiya suggested ideas and assisted in various aspects of the project as needed. D. C. Weindorf assisted with portable X-ray fluorescence (PXRF) spectrometry and manuscript proofreading.

Acknowledgements. We appreciate the support of the golf course superintendents at the local courses in Lubbock, Texas.

Edited by: A. Jordán

\section{References}

Biasioli, M., Barberis, R., and Ajmone-Marsan, F.: The influence of a large city on some soil properties and metals content, Sci. Total Environ., 356, 154-164, 2006.

Bradl, H. B.: Adsorption of heavy metal ions on soils and soils constituents, J. Colloid Interf. Sci., 277, 1-18, 2004.

Clark, J. J. and Knudsen, A. C.: Extent, characterization, and sources of soil lead contamination in small-urban residential neighborhoods, J. Environ. Qual., 42, 1498-1506, 2014.

Dragovic, S., Mihailovic, N., and Gajic, B.: Heavy metals in soils: distribution, relationship with soil characteristics and radionuclides and multivariate assessment of contamination sources, Chemosphere, 72, 491-495, 2008.

Evangelou, V. P.: Environmental Soil and Water Chemistry: Principles and Applications, John Wiley \& Sons. Inc., New York, 1998.

Eze, P. N., Udeigwe, T. K., and Stietiya, M. H.: Distribution and potential source evaluation of heavy metals in prominent soils of Accra Plains, Ghana, Geoderma, 156, 357-362, 2010.

Facchinelli, A.: Multivariate statistical and GIS-based approach to identify heavy metal sources in soils, Environ. Pollut., 114, 313324, 2001.

García-Sánchez, A., Alastuey, A., and Querol, X.: Heavy metal adsorption by different minerals: application to the remediation of polluted soils, Sci. Total Environ., 242, 179-188, 1999.

Gardner, D., Weindorf, D. C., and Flynn, M.: Presence of chromium, copper, and arsenic in schoolyard soils, Soil Horizons, 54, 1-5, doi:10.2136/sh12-12-0032, 2013.

Ge, L., Zhang, Y., Cheng, Y., Zhou, S., Xie, T., and Hou, S.: Proposed correction and influence of drilling fluids in X-ray fluorescence logging, x-ray Spectrom., 26, 303-308, 1997.

Gee, G. W., Bauder, J. W., and Klute, A.: Particle-size analysis, in: Methods of Soil Analysis, Part 1., 2 Edn., edited by: Klute, A., Agron. Monogr. 9. ASA and SSSA, Madison, WI, 383-411, 1986.

Hartley, W. and Lepp, N. W.: Remediation of arsenic contaminated soils by iron-oxide application, evaluated in terms of plant productivity, arsenic and phytotoxic metal uptake, Sci. Total Environ., 390, 35-44, 2008.
Hu, W., Huang, B., Weindorf, D. C., and Chen, Y.: Metals analysis of agricultural soils via portable $\mathrm{x}$-ray fluorescence spectrometry, B. Environ. Contam. Tox., 92, 420-426, 2014.

Jørgensen, K. and Jensen, L. S.: Chemical and biochemical variation in animal manure solids separated using different commercial separation technologies, Bioresource Technol., 100, 30883096, 2009.

Kabata-Pendias, A.: Trace Elements in Soils and Plants, 3rd Edn., (Google eBook), CRC Press, Boca Raton, Florida, USA, 2010.

Laiho, J. V. P. and Perämäki, P.: Evaluation of Portable x-ray Fluorescence (PXRF) sample preparation methods, Geol. S. Finl., 38, 73-82, 2005

Li, X., Wai, O. W. H., Li, Y. S., Coles, B. J., Ramsey, M. H., and Thornton, I.: Heavy metal distribution in sediment profiles of the Pearl River estuary, South China, Appl. Geochem., 15, 567-581, 2000.

Loeppert, R. and Suarez, D.: Carbonate and gypsum, in: Methods of Soil Analysis, Part 3, edited by: Bartels, J. M. and Bigham, J. M., SSSA no. 5. ASA and SSSA, Madison, WI, 437-474, 1996.

McLaren, R. G. and Clucas, L. M.: Fractionation of copper, nickel, and zinc in metal-spiked sewage sludge, J. Environ. Qual., 30, 1968-1975, 2001.

Micó, C., Recatalá, L., Peris, M., and Sánchez, J.: Assessing heavy metal sources in agricultural soils of an European Mediterranean area by multivariate analysis, Chemosphere, 65, 863-872, 2006.

Nelson, D. W. and Sommers, L. E.: Total carbon, organic carbon, and organic matter, in: Method of Soil Analysis, Part 2., edited by: Page, A. L., Agron. Monogr. 9.2. SSSA, Madison, WI, 9611010, 1996.

Nziguheba, G. and Smolders, E.: Inputs of trace elements in agricultural soils via phosphate fertilizers in European countries, Sci. Total Environ., 390, 53-57, 2008.

Rhoades, J. D.: Salinity: electrical conductivity and total dissolved solids, in: Methods of Soil Analysis, Part 3, edited by: Bartels, J. M. and Bigham, J. M., SSSA no. 5. ASA and SSSA, Madison, WI, 417-435, 1996.

Roy, M. and McDonald, L. M.: Metal uptake in plants and health risk assessments in metal-contaminated smelter soils, Land Degrad. Dev., doi:10.1002/ldr.2237, 2013.

Scanlon, B., Nicot, J. P., Reedy, R. C., Tachovsky, J. A., Nance, S. H., Smyth, R. C., and Christian, L.: Evaluation of arsenic contamination in Texas, The Univ. of Texas at Austin, Bureau of Economic Geology, final report prepared for Texas Commission on Environmental Quality, under umbrella contract no. 582-456385 and work order no. UT-08-5-70828, Austin, Texas, USA, 2005.

Selinus, O. (Ed.): Essentials of Medical Geology, Springer Netherlands, Dordrecht, 2013.

Sharma, A., Weindorf, D. C., Man, T., Aldabaa, A. A. A., and Chakraborty, S.: Characterizing soils via portable $\mathrm{x}$-ray fluorescence spectrometer: 3 . soil reaction $(\mathrm{pH})$, Geoderma, 232, 141147,2014

Snowden, C., Ritchie, G., Cave, J., Keeling, W., and Rajan, N.: Multiple irrigation levels affect boll distribution, yield, and fiber micronaire in cotton, Agron. J., 105, 1536-1544, 2013.

Soil Survey Staff: Chemical analyses, calcium carbonate (4E) $\mathrm{HCl}$ treatment (4E1) manometer, electronic (4E1) $<20 \mathrm{~mm}$ basis (4E), in: Soil Survey Laboratory Manual, USDA-NRCS SSRI no. 42, Version 4.0, 269-273, 1996. 
Soil Survey Staff: Web Soil Survey: Soil Data Mart, USDA-NRCS, available at: http://websoilsurvey.nrcs.usda.gov, last access: 5 November 2014.

Sparks, D. L.: Environmental Soil Chemistry, 2nd Edn., Academic Press, California, 2003.

Sposito, G.: The Chemistry of Soils, 2 Edn., Oxford University Press, New York, 2008.

Sposito, G., Lund, L. J., and Chang, A. C.: Trace metal chemistry in arid-zone field soils amended with sewage sludge: I. fractionation of $\mathrm{Ni}, \mathrm{Cu}, \mathrm{Zn}, \mathrm{Cd}$, and $\mathrm{Pb}$ in solid phases1, Soil Sci. Soc. Am. J., 46, 260-264, 1982.

Tack, F. M. G. and Verloo, M. G.: Chemical speciation and fractionation in soil and sediment heavy metal analysis: a review, Int. J. Environ. An. Ch., 59, 225-238, 1995.

Tkalin, A. V., Presley, B. J., and Boothe, P. N.: Spatial and temporal variations of trace metals in bottom sediments of Peter the Great Bay, the Sea of Japan, Environ. Pollut., 92, 73-78, 1996.

Udeigwe, T. K., Young, J., Kandakji, T., and Gautam, P.: Examination of changes in soil chemical properties resulting from irrigation source and turf management in Texas High Plains, ASACSSA-SSSA International Annual Meetings, Tampa, Florida, 3-6 November 2013, 271-13, 2013.

United States Department of Agriculture, National Agricultural Statistics Service: Cotton Ginnings, 2013 Summary, USDA-NASS, available at: http://usda.mannlib.cornell.edu/usda/ current/CottGinnSu/CottGinnSu-05-09-2014.pdf, last access: 5 November 2014.

U.S. Environmental Protection Agency: Method 6200: Field Portable x-ray Fluorescence Spectrometry for the Determination of Elemental Concentrations in Soil and Sediment, USEPA, 2007.

USGA: How Much Water Does Golf Use and Where Does It Come From?, available at: http://www.usga.org/uploadedFiles/ USGAHome/Course_Care/Golf_and_the_Environment/Water/ 214418Lyman,Greg-HowMuchWaterDoesGolfUse.pdf (last access: 4 December 2014), 2012.
Vacca, A., Bianco, M. R., Murolo, M., and Violante, P.: Heavy metals in contaminated soils of the Rio Sitzerri floodplain (Sardinia, Italy): characterization and impact on pedodiversity, Land Degrad. Dev., 23, 350-364, 2012.

Weindorf, D. C., Zhu, Y., Ferrell, R., Rolong, N., Barnett, T., Allen, B. L., Herrero, J., and Hudnall, W.: Evaluation of portable X-ray fluorescence for gypsum quantification in soils, Soil Sci., 174, 556-562, 2009.

Weindorf, D. C., Zhu, Y., Chakraborty, S., Bakr, N., and Huang, B.: Use of portable $\mathrm{X}$-ray fluorescence spectrometry for environmental quality assessment of peri-urban agriculture, Environ. Monit. Assess., 184, 217-227, 2012a.

Weindorf, D. C., Zhu, Y., Haggard, B., Lofton, J., Chakraborty, S., Bakr, N., Zhang, W., Weindorf, W. C., and Legoria, M. Enhanced pedon horizonation using portable $\mathrm{x}$-ray fluorescence spectrometry, Soil Sci. Soc. Am. J., 76, 522-531, 2012 b.

Weindorf, D. C., Herrero, J., Castañeda, C., Bakr, N., and Swanhart, S.: Direct soil gypsum quantification via portable $\mathrm{x}$-ray fluorescence spectrometry, Soil Sci. Soc. Am. J., 77, 2071-2077, 2013a.

Weindorf, D. C., Paulette, L., and Man, T.: In-situ assessment of metal contamination via portable $\mathrm{x}$-ray fluorescence spectroscopy: Zlatna, Romania, Environ. Pollut., 182, 92-100, 2013b.

Yu, K. C., Tsai, L. J., Chen, S. H., and Ho, S. T.: Correlation analyses on binding behavior of heavy metals with sediment matrices, Water Res., 35, 2417-2428, 2001.

Zhu, Y. and Weindorf, D. C.: Determination of soil calcium using field portable X-ray fluorescence, Soil Sci., 174, 151-155, 2009. 